\title{
Literature Abuse, or the Motive of the Guilt and Punishment of the Reader
}

\author{
Olga N. Turysheva* \\ Ural Federal University named after the B.N. Yeltsin \\ 19 Mira Str., Ekaterinburg, 620002, Russia
}

Received 17.10.2014, received in revised form 21.05.2015, accepted 14.06.2015

\begin{abstract}
The purpose of the present article is the analysis of a literature abusing reader image. The motive of a reader guilty of literature abuse and the nature of its functioning are studied on the basis of some works of modern literature. The author connects the specifics of the motive with the reflexive reaction of literature to "anarchical", consumerist reading wide-spread in modern culture. The narrative forms dedicated to literature abuse are researched. Among them there is a motive of punishing the reader and expiation of the reader's guilt. The author comes up with the hypothesis that the motive formation is associated with the response to the ideas of modern receptive theory.
\end{abstract}

Keywords: pictured reader, the motive of guilt of literature abuse, the motive of literature resentment towards the reader, the motive of reader's punishment, the theme of reading in the literature.

DOI: 10.17516/1997-1370-2015-8-7-1315-1324

Research area: philology.

The reader has been a character of fiction literature since long ago. For the first time the reader's image got in the centre of attention back in Medieval Europe where, by the end of the historic period, a new and seemingly unexpected theme was formulated: the theme of literature's guilt towards the reader. For the first time this motive was clearly expressed in the stories of Hamlet and Don Quixote. These heroes of late Renaissance went through deep disappointment in the illusion they found in books. Thus, Cervantes, bringing the story of Don Quixote to its end, speaks through him, articulating the bitter curse of knight novels, blaming them for the utopia of his own worldview. Shakespeare, in his turn, invests the character with scepticism of the book truths from the very beginning of the tragedy. This scepticism is clearly heard in Hamlet's reply to Lord Polonius' question of what he was reading: "Words, words, words..."

Thus, the motive of resentment towards literature was formed in the late Renaissance literature. Throughout the next centuries this motive has been multiply incarnated in stories about the readers whose expectations brought up by literature never came true and turned to be a bitter disappointment ${ }^{1}$. The guilt of literature was formulated (by the character or the author) as creating an illusory consciousness, plunging the reader into the world of dreams, suggesting

(C) Siberian Federal University. All rights reserved

* Corresponding author E-mail address: oltur3@yandex.ru 
an untruthful explanation of reality, promising unachievable resort, and finally, depriving the reader of an opportunity to live his life by himself, offsetting the individuality of his perception. The most expressive examples of this motive are "Madame Bovary" by Gustave Flaubert, novella "Notes from Underground" by F.M. Dostoyevsky, novellas "Bibliomaniac" by J. Nodier, parable "Book Man" by H. Hesse, novel "The Blinding" by E. Canetti, novel "The House of Paper" by C.-M. Dominguez etc.

However, at the end of the $20^{\text {th }}$ century the understanding of relationships between the reader and the book took another twist. In the latest stories of reading it is not the reader's resentment towards literature that is emphasized; it is, vice versa, the resentment of literature towards the reader. This motive appears frequently enough to speak of a new motive, the motive of the reader's guilt towards literature. The present article suggests some initial remarks on the functioning of such a motive in modern fiction.

It seems evident that the development of this motive as such is connected to the popularity of such type of reading where the content of the book becomes the object of the upmost frivolous exploitation by the reader. In modern receptive studies such frivolousness is understood as a consequence of the new "reading order" that appeared in the post-book epoch. The French historian and philosopher of reading, Roger Chartier, who invented the concept of "reading order" and described its changes in the history of human culture, associated the modern period with the emergence of so-called "anarchic reader" (Chartier, 2006). According to R. Chartier, an "anarchic reader" is a reader who has no interest in doing any interpretation work over the text; in the process of perception he relies on nothing but his own right of free, unrestricted reading; he claims to possess the total power over the semantics of the text with no regard to what is usually referred to author's intention or strategy of text. In such a situation the only purpose of the reader's interaction with the art of word is satisfaction of the reader's selfish emotional and psychological needs (such as neutralization of negative experience, arrangement of leisure, imaginary modelling of his own image with the help of the text). The main distinctive feature of the traditional reading order, which is the essential interpretation work, recognition of the primary right of the text itself, the desire to see into the author's intention and the attitude to the book as a source of experience (moral, cognitive, emotional), in the current cultural situation is often replaced with the mere pursuit the reader's "profits". In the age of Web 2.0 such type of reading became so wide-spread that, according to our hypothesis, it caused a direct reply from literature itself. We associate this reaction with the formation of a specific literary motive, the motive of literature's resentment towards the reader. In its most radical form, the motive is combined with the motive of punishing the reader, and in the most optimistic form it brings the motive of expiation of guilt.

To our mind, in Russian literature this theme was outlined in "The Slynx" by T. Tolstaya (2000). The type of perception demonstrated by the main character of the novel, Benedikt, is purely consumerist. The only reason why Benedikt reads is the desire to cope with boredom, to fill his leisure with the sweet fantasies of himself in the place of book characters: "There's nothing to do... It's boring", he whines. Reading, Benedikt passionately identifies himself with the book characters: "And they all throw themselves joyfully into the arms of their beloved. And just who is their beloved? Why, it's Benedikt, of course, whether he's called Don Pedro or Sysoy" (Tolstaya, 2007, p. 200). T. Tolstaya seems to be satirically and grotesquely depicting the phenomenon of a reader's self-identification 
with the book world, previously described in the works of German receptive aesthetics. However, in the case of Benedikt, due to its aggressive and selfish character, identification is surprisingly correlated to skin-changing. That is exactly the way Benedikt describes his reading himself: "You read... and it's like you're in two places at the same time ... you can live as many different lives as there are books to read. Like a werewolf or something..." (ibid, p. 183).

The final result of such reading, depicted in the novel, is transformation into a beast, a creature similar to the slynx. T. Tolstaya concentrates on depicting the process of ultimate dehumanization of Benedikt. The traditional motive of moral education of the reader, typical of the $19^{\text {th }}$ century literature, is turned inside-out: reading does not make any ethic impact on the protagonist; on the opposite, it enhances his degradation as a human. It is exactly the consumerist attitude of Benedikt to literature this process is caused by. It is expressively confirmed by the fact that every book evokes nothing but disappointment in him, because when it finishes, it brings the sadness back into this heart, interrupting the sweet illusory trip into the world of books. This is how a text turns into a one-off thing. Re-reading a book, the protagonist feels "no emotion, no trembling or anticipation of things to come": "What to do now? What to live for? Once again, he had a feeling of alarm, as if he'd lost himself" (Tolstaya, 2007, p. 211). It leads to his aggression to the author and appropriation of the author's rights for the meanings of the book, for the "letters", as Benedikt calls them. Not without reason, laying his claims to Pushkin for not giving him a clear idea of "how he should live", he insists on his authorship of the poet himself: "I hacked you out of a dumb log all by myself ... Without me you would be an eyeless chunk, an empty log, a nameless tree in the forest ... Without me - you wouldn't be here! Who was it, with iniquitous power, called me forth from nothingness? - It was me, I called you! I did!" (ibid, p. 262).

Besides the motive of skin-changing, the consumerist attitude of Benedikt to books is confirmed with another metaphor: T. Tolstaya constantly correlates his reading to the process of eating. The intake of food and the process of digestion serve as a metaphor for naïve, empathic, non-reflective, "culinary" (after H.-R. Jauss (Jauss, 1995)) readership.

In the context of the foregoing, the multiple allusions to Pushkin, accompanying the image of Benedikt, seem paradoxical at first. However, they are convincingly confirmed by N. Kovtun, who remarks some correlations between the characters surrounding Benedikt and the real characters of Pushkin's biography (The Head Stoker Nikita Ivanovich - Nikita Kozlov, Olenka - Natalya Nikolaevna Goncharova, Anna Petrovna, an Oldener "crone" - Anna Kern etc.)

Another stroke of great significance is the final phrase of Benedikt repeating the last words of Pushkin ("The life is over") (Kovtun, 2014, p. 90-94). N. Kovtun interprets these correlations as a form of parodical deconstruction of one of national myths of Russian culture: the myth of Pushkin (Kovtun, 2014, p. 84)2.

Within the given aspect, let us add that for T. Tolstaya it is not only the sacralisation of Pushkin himself as a national genius that acts as an object of ironical profanation; it is also the idea of universality, availability, suitability and vivification properties of his works for any reader. With the example of Benedikt Tolstaya explicitly demonstrates that Pushkin cannot belong to each and every one; that the appropriation of Pushkin (like in "My Pushkin") can easily lead to transformation of the poet into a "pure retard" and "moron" as one of the Oldeners characterized the idol crafted by Benedikt. An ignorant reader degrades Pushkin into a pushkin, which, however, hardly brings his sacral status 
in culture to discredit. There is no coincidence that the Oldeners, ascending to the sky, merrily cancel the tragic pathos of Pushkin's last words unknowingly quoted by Benedikt ("The life is over" - "It's over... So we'll start another one"). The words of Pushkin (or, to be more precise, the "letters"), instinctively absorbed by Benedikt, are not transformed into meanings, just like the parallelism of his story with Pushkin's biography just "did not work out" in his story, leading to nothing but complaint of the author for "not having taught how he should live". Of course, in the novel it is the complaint of the reader who attempted to appropriate Pushkin, being incapable of doing the work of reading. As we find out, Pushkin cannot transform each and every one into a human; the only positive consequence of his presence in Benedikt's life was the amputation of tail, which, however, did not prevent Benedikt from eventual transformation into the slynx. But, according to Tolstaya, each and every one can turn Pushkin into a bent pinocchio-idol.

It is also suggested that, insisting on the parallel between Pushkin and Benedikt and letting the latter claim to be the creator of the poet himself ("Without me - you wouldn't be here! "Who was it, with iniquitous power, called me forth from nothingness? - It was me, I called you! I did!"), Tolstaya mocks at the poststructuralist concept of the reader as the main agent of meaning-making: the concept borne on the basis of the author's death idea. According to Tolstaya, the author only dies (Pushkin turns into pushkin) in the activity of a reader described through Benedikt.

The motive of punishing such a reader is not deployed, but roughcast in the novel: in the final episodes marking Benedikt's defeat, when the Oldeners merrily ascend to the sky leaving him alone on the burnt ground with the instruction to "study his letters". Obviously, this instruction assumes the necessity to understand the copybook maxims in the experience of communication with the book. The $\mathrm{ABC}$ of reading assumes seeing the book as the source of thought, feeling and experience, not a product of consumption. Unfortunately, the latter is never the domain of "golubchiks", as T. Tolstaya named the ignoramuses of the post-apocalyptic epoch that came after the Explosion destructing all culture. For example, Woody Allen chooses to tell the story of an English literature professor as a reader with purely consumerist attitude to books. His short story "The Kugelmass Episode" (1980) contains a well-deployed motive of punishment of the reader guilty towards literature.

The plot of the story is fantasy: with the help of a magic machine, the protagonist penetrates into the inner world of the novel by G. Flaubert "Madame Bovary". His purpose is to find new sensual impressions in the book. Unsatisfied with his marriage, he becomes a lover of the French novel heroine. Traveling from the novel world into his real life and back, periodically bringing Emma Bovary with him, Kugelmass destroys the narrative texture of Flaubert's novel, horrifying and confusing his researchers and readers. In the end, for having selfishly infringed on the classic story in order to please his erotic fantasies, the protagonist is placed into a Spanish textbook, where he was condemned to "running for his life over a barren, rocky terrain as the word tener ("to have") - a large and hairy irregular verb - raced after him on its spindly legs" (Allen, 2001, p. 149).

Let us pay our attention to the fact that, if in the novel by Tolstaya, the consumerist attitude to a literary text is incarnated in the metaphor of food intake, in the story by W. Allen the metaphor is rougher: it is a metaphor of seduction and compulsion. Therefore, in the deeds of the anarchic reader of $\mathrm{W}$. Allen the text suffers violence similar to sexual. 
The motive of the reader's guilt associated with the egoistic infringement on the wholeness of the classic text also underlies the screenplay for the TV series "Lost in Austen" by Modern English playwright Guy Andrews. The movie came out in Britain in 2008. The title of the series was translated into Russian as Ожившая книга Джейн Остин ("The Book by Jane Austen That Came Alive"). At first, the screenplay seems to be a female version of the story told by W. Allen in "The Kugelmass Episode". It is the story of a modern girl called Amanda Price, a passionate fan of "Pride and Prejudice" by Jane Austen, who miraculously finds herself inside her favourite novel, cherishing a hope for the love of Mister Darcy. Just like Kugelmass, she frivolously plays in the inner space of the novel, bending the behaviour of literary characters to her will and parasitically modelling her own story on the basis of their lives. Presenting the reader's guilt in a way similar to that of the story by Woody Allen, Guy Andrews solves the question of punishment of such extremist reader very differently.

However, let us first concentrate on the "crime" of Amanda Price. It is again committed as a result of self-identification with a literary protagonist. In this case, it happens due to Amanda's dissatisfaction with her own love affair. Together with it, her reader's self-identification makes an aggressive impact on the novel. In order to satisfy her desire to be the object of Darcy's love, she bends the development of the novel to her fantasies, turning the classic plot upside down. Having eliminated Elizabeth Bennet from the narration, she garners sympathy of Mister Bingley, which, in its turn, results in the absurd marriage between Jane Bennet and Collins, and even a more absurd kidnapping of Lydia by Bingley, drowning his disappointment in wine and frenzied actions. Amanda, however, makes a conquest of Darcy and forces him to get engaged with her.
However, at a certain moment the situation gets out of Amanda's control: Darcy believes the insinuation of Miss Bingley, breaks off his engagement to her and plans a revengeful marriage with Caroline. Desperate, Amanda disposes of the novel in the most violent way: she furiously tears the book and throws it out of the window. The book that failed to satisfy her wish suffers the revenge, which aggravates the reader's guilt.

At the same time Amanda realizes that in her frivolous violence over the story she cannot make her matrimonial expectations come true. In the movie, the reason of the invariable failure of the heroine is caused not by the extraordinariness of her purpose, but by the character of her reading as such. It turns out that she is the only one to be blamed for causing the hatred of Miss Bingley breaking her engagement with Darcy, for she has appropriated homosexual orientation to the unloved heroine. But, having decided to take her change out of Miss Bingley, Amanda does not wish to admit her guilt. To prevent Miss Bingley's alliance with Darcy, she hurries to put the novel story into order, and due to her efforts Lydia returns home and Bingley, finally, reunites with Jane. Amanda sets out on a search for Elizabeth she left in her reality. However, Elizabeth refuses to leave the $21^{\text {st }}$ century England for the world of her novel. She has read the novel by Austen to find out that she has been married to Darcy for over two hundred years. Obviously, she finds it enough, and steps back easily, leaving Darcy to Amanda. As a result, Amanda wins the heart of Mister Darcy and becomes the lawful landlady of Pemberley.

The author's position towards the "crimes" of Amanda is controversial. On one hand, the self-will of perception is reproached, which is proved by the ironical tone of the series and direct disclosure of the heroine's trickery. However, on the other hand, the final scenes of the movie are 
sympathetic to Amanda. The story of the reader's selfishness comes to a happy end. Truth be told, the happy end is achieved only thanks to the ridiculous admission that Elizabeth might agree to work as a nanny in modern London and let go all of her claims to Darcy.

Such an end of the story of anarchic reading seems to be an artificial excuse for reader's aggression and frivolousness. Even the momentary repentance of the heroine does not excuse such an ending, as all the attempts of Amanda to put everything back in order are not caused by her shame for having destructed the novel; they originate from her disappointment of the ability to do anything she wants. The final where everyone return to their places would look much more natural: Elizabeth would go back to Longbourn to live her story with Darcy, and Amanda would return to the $21^{\text {st }}$ century London to live her own life with the wisdom she found in books.

In the ending chosen by the authors of the series, the final of the anarchist reader story does not look convincing. Especially it does not, when compared the story by W. Allen who presented, as we have already shown above, a similar story, finished in the opposite, the only fair way, which is the punishment of the reader with the consumerist attitude to classic texts.

Let us formulate our assumption on the reasons why the British playwright did not choose the accusing ending for his story. "Lost in Austen" was written almost 30 years after the story by W. Allen, and the differences in the judgment of the readers' behaviour may be explained by the changes that have happened in the sphere of literary communication within the past decades. The first of them is the elimination of the strict order that used to be typical for reading classic literature. Another type of reading, the one intended to bring a hedonistic result, not work on meanings, becomes much more popular.
Using the term by J. Ortega y Gasset (Ortega y Gasset, 2002), the "average" reader does not wish to bear the enforcing effect of the text; he wants to own the text and use it as a tool to solve his own problems. Obvious indulgence to such type of reader, to our mind, caused the final support of the protagonist shown by the series producers.

Besides, modern literature offers some plots with the expanded semantics of reproach to the reader who abused literature. It is no coincidence that the protagonists of such stories are professional readers, philology teachers. In the novel by French writer Jean-Philippe Arrou-Vignod "Le Conseil d'Indiscipline" (1995) the guilt of such a reader towards literature is connected to the reader's attempt to debunk the great significance of literature. The protagonist of the novel, French literature teacher called Beaujeu, is going through a deep existential crisis, shifting the blame for the life with permanent caution to moral principles to literature itself. Longing to "break free", he leaves his home. The core of his house is the library, collected with great love. For the protagonist suffering from doubts, the library becomes the symbol of rejection of his real life, the symbol of obeying to the ethics of classic literature and, therefore, the symbol of rebellion.

Wishing to "oppress a moralist in himself", the protagonist leaves the family for his mistress, whose life and place of residence ("a dirty and overcrowded quarter ... an erotic antidote for the strict and solemn serenity of books" (ArrouVignod, 2002, p. 63) seem to be the picture freedom to him. However, the project of opposition to literature reveals its delusiveness at once. Having faced the carnivalesque disillusionment, Beaujeu escapes again. But he cannot return to his previous life, enlightened by exalted literary texts: in the act of angry return, he loses the keys of his apartment. Returning to the library becomes impossible. 
The loss of keys is more than just a symbolic detail; it is an evident reference to the punishment of the protagonist. The library rejects its previous keeper, thereby depriving him of all existential support. The character of Arrou-Vignod receives a pitiful defeat in the rebellion against literature. Basically, the narration is constructed in a grotesque and ironical key. The author's irony seems to be another aspect of punishment of the abjurer reader besides the one presented in the story.

Modern literature telling the stories of readers who abuse literature also develops a motive of expiation of guilt. In such a case, the story of the reader consists of "crime" - "punishment" "expiation". This motive set underlies the narration of the fantasy novel by American writer James Hynes “The Lecturer's Tale" (2001). The object of the crime, and, at the same time, the executor in the novel is literature itself, materialized in the image of a ghost taking a cruel revenge upon philology teachers. The reason for the revenge is the university philologists' understanding of their work as endless production of ridiculous hyperinterpretations of literature in pursuit of titles and honorariums. The main character of the novel is the university teacher Nelson Humboldt, who calls such literary studies "struggle with the dead" (Hynes, 2004, 210): in Hynes's grotesque and sarcastic manner of narration such hermeneutic practice is not a form of studying literature and confirmation of its importance; it is a way of murdering it. It makes literature lose its inherent value, turning into material for irresponsible and mercenary philological scribbles.

The ghost of insulted literature lives its secret life in the tower of Thornfield Library, the name for which does not only deploy the caravan of obvious allusions, but also vectors the development of the plot. Just like in the famous Victorian story of insane Berta prisoned in Thornfield Hall, the ghost of literature, pushed away from the classrooms and professors' offices into the library, begins its revenge, being, at the same time, doomed to death.

The ghost satisfies its desire for revenge upon different philologists of the university in different ways. So, Nelson finds himself selected as a "representative" of the ghost in the world of "literature killers": on one hand, the ghost exposes him to physical punishment, which can be symbolically interpreted as initiation (to become his servant), and on the other hand, it induces him with magical abilities: after the magic transformation, Nelson acquires the ability to influence people and bend them to his will. However, the protagonist fails to reveal the ghost's intention. Instead of saving his overlord, Nelson uses the magic in order to achieve a higher title.

The punishment of the character is more severe than just deprival of his magic power; he is forced to watch a horrible scene when the ghost of literature materialized the principle of research practiced by philologists: assigning the text with inadequate meanings, complete perversion of its semantics and symbolic murder. Nelson evidences the performance as a spectator, while the material for demonstration is the body of Nelson's colleague Vita Deonne, a feminist critic, the body combining some opposite features (being a man, she claims to be a woman). Obviously, such an "ambivalent", "polysemantic" body was selected by the ghost to demonstrate the way how ambivalence of a phenomenon meaning can be insulted upon in the act of deconstruction. Exposing Vita's body to monstrous, Bosch-esque transformations, the ghost materializes a series of post-structuralist philological ideas, firstly the idea of denying the entirety of text and certainty of meaning.

The protagonist is punished with more than just the horror of witnessing the violence, but also the pangs of conscience due to his 
own involvement in the fire that happened in Thornfield Library. In the final scene of the story, Nelson goes through a cathartic rebirth: breaking free from the theoretical hassle and power ambitions, he asserts the idea that "everything that is needed" is nothing but the text of the book. Entering the classroom without his notes and critical works, instead of reading another lecture he recites "David Copperfield" by Dickens from memory. The separately preannounced title of the first chapter of the novel, "I am born", undoubtedly acquires a symbolic meaning of a new start in his situation. Basically, the "new life" of the protagonist begins when he witnesses the horrible performance demonstrated by the ghost: the chapter telling the story of the terrifying scene played to enlighten Nelson bears a Dante title "La vita nuova". Therefore, its content provokes associations with limbo. Evidently, the protagonist is ready to devote his new life to the resurgence of "the great dead" in teaching literature and construction of a new university library. The idea of bringing literature in the form of living word instead of a repressed ghost back to the classrooms finishes the story.

The theme of the reader's guilt and forgiveness is fantastically incarnated in the "Inkheart" trilogy by German writer C. Funke, comprising "Inkheart" (2003), “Inkspell” (2005), and "Inkdeath" (2007). In this case the reader's guilt is connected with the lack of respect to the entirety, completeness, selfconsistency of the literary world, its laws and the wisdom of its organization. The guilty one is a young reader called Meggie who has a magic gift of bringing literary characters to life and to materialize the story events. Wishing to neutralize the evil which can break out from the book due to her reading activity, she tries to "re-write" the story, to adjust it to her own idea of how the events are meant to be. Let us emphasize that her interference with the story does not pursue the objective to bend the story to her selfish will (as in the case of consumerist reading we have observed in the story by W. Allen and the "Lost in Austen" series). Meggie wishes to intercept the evil which can get beyond the literary world and break into the real one. Her noble intentions are expressed in heroic, self-sacrificing deeds.

However, Meggie's interference with the concept of the book causes some truly tragic consequences. They are the subject matter of the last books of the trilogy, the plot of which is unwound within the "ink" world, the inner world of the book read by the protagonist. In the story by C. Funke, this world is able of living and developing despite the will of its own creator, Fenoglio the storyteller. By the way, he also travels into the reality of his own story and takes direct participation in all of its events, noticing with surprise that they hardly depend on his fantasy as their author. This way Funke unambiguously demonstrates that the conceptual meaning of literature depends more on the reader's activity, than on that of the writer.

Having entered the inner space of the book, the young reader is horrified by the destructive process it suffers under the influence of her reading: the inner harmony of the world is broken, and the balance between good and evil is lost. No surprise that in the final scene Meggie arrives at penitential understanding of the way the careless and frivolous interference into the book world, even moved by good intentions, brings nothing but death and destruction to both the book and the reader.

As a rule, the stories of the reader's guilt end with the restoration of the literature status and the laws underlying the inner organization of the book. Such an ending is usually achieved either by depiction of the repentance of the guilty reader (as in novels by C. Funke and J. Hynes), or by depiction of revolt of the offended literature 
or its substitutes and representatives (as in books by T. Tolstaya, W. Allen, J.-F. ArrouVignod). However, this tendency is broken by the cinematographic text by $\mathrm{H}$. Andrews which seemingly ends with the excuse of the reader's free will. However, in this piece we also find a motive of guilt admittance, but at the end it is neutralized by the author's forgiveness of the reader's selfishness. We explain this paradox with the strengthening position of the mass reading culture, which even several decades ago was considered to be a low-rank culture which does not deserve the attention it enjoys now (Kul'ttovary, 2009, 2012).

However, in any option of the story ending, the plots of the reader's guilt obviously respond to the tendencies of the modern receptive situation. Let us repeat that it is caused by the expansion of anarchic, consumerist reading (also in the professional reader environment), as well as loss of trust and respect for the logic and the wholeness of the literary world carefully created by the writer.

It appears that the manifestation of such tendencies in literature is directly caused by the attention to modern theoretical tendencies. Having accepted the idea of the author's death, the perception studies of the $20^{\text {th }}$ century began to speak of the reader's inevitable participation in the creation of the conceptual side of the book. In its turn, the research of such participation mechanism revealed how much reading is connected to the self-construction of the reader's personality. Creative expression of these ideas in the books with the reader's guilt plot lets literature set the problem of the reader's responsibility both to the text he reads and to himself. The destiny of the reader turns to be proportionally related to his attitude to the book, as well as the character and purposes of his conceptual activities. The relevance of this problem in the reading order change epoch is doubtless.

Read more in my article: Razocharovanny y chitatel', ili Motiv obidy na literature [The Disappointed Reader, Or The Motive Of Resentment Towards Literature] // Filologicheskie nauki. Nauchnye doklady vysshey shkoly. 2011. No.4 (JulyAugust). P.23-33.

2 Another important work on the Pushkin myth mentioned in the present article: Zagidullina M.V. Pushkinskiy mif v kontse XX veka [Pushkin Myth In The Late $20^{\text {th }}$ Century]. Chelyabinsk, 2011. 329 p.

\section{References}

1. Allen, W. Sluchay s Kugelmasom [The Kugelmass Episode], translated from English by O. Dorman // Inostrannaya literatura. 2001, No.1, P. 143-149.

2. Arrou-Vignod, J.-F. Urok neposlushaniia [Le Conseil d'Indiscipline], translated from French by N. Kulish // Inostrannaya literatura. 2002, No. 6, P. 3-80.

3. Zagidullina M.V. Pushkinskiy mif $v$ kontse XX veka [Pushkin Myth In The Late 20th Century]. Chelyabinsk, 2011. 329 p.

4. Kovtun N. Real'nost' i text v proze rubezha XX-XXI vekov: "Posledniy mir" K. Ransmayra $i$ "Kys", T. Tolstoy [Reality And Text In The Prose Of The Late $20^{\text {th }}-$ Early $21^{\text {st }}$ Centuries: "The Last World" By K. Ransmayr And "The Slynx" By T. Tolstaya] // Krizis literaturotsentrizma. Utrata identichnosti vs. Novye vozmozhnosti: monografiia [Literaturecentrism Crisis. Loss Of Identity Vs. New Opportunities: Monofraph], edited by N. Kovtun. Moscow: Flinta: Nauka. P. 69-94.

5. Kul't-tovary: fenomen massovoy kul'tury v sovremennoy Rossii [Cult-Commodities: Mass Literature Phenomenon in Modern Russia]: collection of articles. Edited by I.L. Savkina, M.A. Cherniak. Saint Petersburg, 2009. 336 p. 
6. Kul't-tovary-XXI: reviziia tsennostey (masskul'tura $i$ ee potrebiteli) [CulCommodities-XXI: Values Revision (Mass Culture And Its Consumers]: collective monograph. Edited by I.L. Savkina, M.A. Cherniak, L.A. Nazarova. Yekaterinburg, 2012. 272 p.

7. Ortega y Gasset, J. Vosstanie mass: sbornik [Revolt Of Masses: Collection of Works]. Moscow: Ast, 2002. 506 p.

8. Tolstaya T. Kys' [The Slynx]. Moscow: Exmo, 2007. 368 p.

9. Turysheva O.N. Razocharovannyy chitatel', ili Motiv obidy na literaturu [The Disappointed Reader, Or The Motive Of Resentment Towards Literature] // Filologicheskie nauki. Nauchnye doklady vysshey shkoly. 2011. No.4 (July-August). P.23-33.

10. Funke C. Chernil'noe serdtse [Inkheart]. Translated from German by N. Gladilin, M. Sokol'skaia, I. Sotnikov. Moscow: Rosmen-Press, 2005. 589 p.

11. Funke C. Chernil'naia krov' [Inkspell]. Translated from German by M. Sokol'skaia. Moscow: Makhaon: Azbuka-Attikus, 2012. 653 p.

12. Funke C. Chernil'naia smert' [Inkdeath]. Translated from German by M. Sokol'skaia. Moscow: Makhaon: Azbuka-Attikus, 2012. 672 p.

13. Hynes J. Rasskaz lektora [The Lecturer's Tale]. Translated from English by E. DobrokhotovaMaykova. Moscow: AST: Lux, 2004. 461 p.

14. Chartier, R. Pis'mennaia kul'tura i obschestvo [Written Culture and Society]. Translated from French by I.K. Staf. Moscow: Novoe izdatel'stvo, 2006. 272 p.

15. Jauss H-R. Istoriia literatury kak provokatsiia literaturovedeniia [Literary History As A Challenge To Literary Theory], translated from German. // Novoe literaturnoe obozrenie, 1995, No. 2. P. 34-84.

\section{Оскорбление литературы,}

\section{или Мотив вины и наказания читателя}

О.Н. Турышева

Уральский федеральный университет имени Б.Н. Ельцина Россия, 620002, Екатеринбург, ул. Мира, 19

Целью статьи является анализ образа читателя, обидевщего литературу. Характер функиионирования мотива вины читателя перед литературой исследуется на материале отдельных произведений современной словесности. Специфика воплощения мотива связывается с рефлексивной реакцией литературы на распространение в культуре новейтего времени «анархического», потребительского чтения. Исследуются сюжетные формы, в которые воплощается тема оскорбления литературы. Среди них - мотив наказания читателя и мотив искупления читательской вины. Выдвигается гипотеза о том, что формирование данного мотива связано с откликом литературы на идеи современной рецептивной теории.

Ключевые слова: изображенный читатель, мотив вины перед литературой, мотив обиды литературы на читателя, мотив наказания читателя, тема чтения в литературе.

Научная спещиальность: 10.00 .00 - филологические науки. 